\title{
Molecular Identification of Fungi Associated with Vascular Discoloration of Soybean in the North Central United States
}

\author{
T. C. Harrington, J. Steimel, F. Workneh, and X. B. Yang, Department of Plant Pathology, Iowa State University, \\ Ames 50011
}

\begin{abstract}
Harrington, T. C., Steimel, J., Workneh, F., and Yang, X. B. 2000. Molecular identification of fungi associated with vascular discoloration of soybean in the north central United States. Plant Dis. 84:83-89.

Brown stem rot is a common but poorly understood vascular wilt disease of soybean. In order to more clearly delimit the causal agent (Phialophora gregata) and distinguish it from other morphologically similar fungi from discolored soybean stems, fungi were isolated on a semi-selective medium from discolored and non-discolored soybean stems collected at random across Iowa, Illinois, Minnesota, Missouri, and Ohio. A total of 11 fungi were commonly isolated and characterized based on colony morphology and DNA sequences of the internal transcribed spacer region of the rDNA operon. Phomopsis longicolla was the most frequently isolated fungus, but it was isolated more commonly from lightly discolored or non-discolored stems than from discolored stems. Phialophora gregata was the next most frequently isolated fungus and was isolated more commonly from discolored stems and more commonly in 1996 than in 1995, which had a warm growing season and relatively little brown stem rot. In inoculation experiments, only $P$. gregata was capable of causing the vascular discoloration and leaf symptoms typical of brown stem rot; none of the seven isolates could be considered non-defoliating. Two other fungi, Plectosphaerella cucumerina and Gliocladium roseum, were similar in colony morphology to Phialophora gregata but were not pathogenic to soybean, and these may be the same species as those referred to by earlier workers as Acremonium spp. or the non-defoliating form of $P$. gregata.
\end{abstract}

Additional keywords: Cladosporium tenuissimum, Diaporthe phaseolorum, Fusarium spp., Glycine max, Macrophomina phaseolina

Brown stem rot (BSR) is one of the most important diseases of soybean (Glycine max (L.) Merr.) in the north-central soybean-production region (10), yet the causal agent of the disease is poorly known. The disease is characterized by a browning of the vascular system and pith, and characteristic chlorosis and necrosis of the foliage develops late in the season, usually in August (2). However, similar vascular discoloration is found late in the season with other diseases of soybean. Some BSR-resistant germ plasm is available $(3,24)$, mostly identified by the extent of vascular browning, but development of resistant cultivars and deployment of resistance have been hampered by imprecise resistance rating, a poor understanding of

Corresponding author: T. C. Harrington

E-mail: tcharrin@iastate.edu

This project was supported in part by the Iowa Soybean Promotion Board. Journal Paper No. J18309 of the Iowa Agriculture and Home Economics Experiment Station, Ames, Iowa, Project No. 3226, and supported by Hatch Act and State of Iowa funds.

Accepted for publication 29 September 1999.

Publication no. D-1999-1115-02R

(C) 2000 The American Phytopathological Society the causal agent of the disease, and uncertainty about the variation in aggressiveness in the pathogen $(16,24,29,33)$.

The pathogen was described as Cephalosporium gregatum in 1948 by Allington and Chamberlain (2). Unfortunately, the fungus forms rather nondescript conidiophores, phialides, and conidia, and many unrelated species are morphologically similar. Many Cephalosporium spp. are now placed in the heterogeneous genus Acremonium, but the proper generic placement of $C$. gregatum is still in question. Gams (14) transferred the species to the genus Phialophora, though the fungus generally produces non-pigmented conidiophores. Sequences of ribosomal DNA suggest that Phialophora gregata is an anamorph of a discomycete (T. C. Harrington, unpublished).

Two or more Acremonium-type fungi that are similar to $P$. gregata have been associated with brown stem rot in soybean and adzuki bean $(5,18,23)$, and at least one of these Acremonium spp. causes vascular discoloration in soybean (23). Gray (16) reported that the disease in soybean is caused by either of two forms of $P$. gregata, a defoliating form (type I) and a nondefoliating form (type II), with the latter causing vascular discoloration but no foliar symptoms. Gray and Hepburn (18) did not distinguish type I and type II isolates of $P$. gregata. Phillips (29) found at least three virulence genotypes of $P$. gregata based on vascular discoloration, and Willmot et al. (33) distinguished type I and type II isolates based on foliar symptoms. Mengistu and Grau (23) also recognized type II isolates of $P$. gregata and isolates of an unidentified Acremonium sp. that caused vascular discoloration but limited foliar symptoms. Later, Mengistu et al. (25) characterized type II isolates as growing faster than type I isolates, while the opposite was reported by Gray (16), and their (25) illustration of type II colonies show them to be atypical of $P$. gregata. Although it is not clear if type II isolates (sensu Gray, 16; Willmot et al., 33; and Mengistu et al., 25) are $P$. gregata or another Acremonium-type sp., we examined isolates of the Acremonium spp. of Mengistu and Grau (23) and found them to be Plectosphaerella cucumerina (Lindf.) Kleb. (anamorph = Plectosporium tabacinum (van Beyma) M. E. Palm), a common pyrenomycete in soybean and other plants that may be pathogenic to some hosts $(6,27,28)$. Because its anamorph is similar in morphology to Phialophora gregata, it is possible that Plectosphaerella cucumerina was misidentified as the so-called "non-defoliating" form of Phialophora gregata in earlier studies $(16,25)$. Gray and Hepburn (18) also found that some adzuki bean isolates identified as $P$. gregata were likely an unrelated Acremonium sp., and conidia and conidiophores of their fungus look similar to the anamorph of Plectosphaerella cucumerina. The brown stem rot pathogen in adzuki has recently been designated as a distinct specialized form, Phialophora gregata f. sp. adzukicola (21).

With the advent of polymerase chain reaction (PCR), inexpensive DNA sequencing, and a relatively large databank of ribosomal DNA sequences, it is now possible to more objectively characterize and identify fungal species. We applied these techniques to fungi associated with brown stem rot of soybeans. Our objectives were to clarify the etiology of this disease, more clearly characterize the causal agent, and delineate the pathogen from similar fungi isolated from vascular discoloration in soybean, using a larger number of isolates and sampling a wider geographic area than had been utilized in earlier studies. 


\section{MATERIALS AND METHODS}

We used the semi-selective medium of Mengistu and Grau (25) to isolate from stems collected from randomly selected soybean fields in the Midwest at the end of the 1995 and 1996 field seasons. The isolated fungi were tentatively categorized to species by colony morphology and restriction fragment length polymorphisms (RFLP) of the internal transcribed spacer region (ITS) of the nuclear ribosomal DNA. The complete DNA sequences of the ITS region were used to aid identification. Nine of these fungi were inoculated into soybean in order to determine which are capable of causing the symptomatology characteristic of brown stem rot.

Isolations. In a separate study (34), 1,462 soybean fields in Iowa, Illinois, Minnesota, Ohio, and Missouri were randomly sampled in 1995 and 1996, based on stratification of counties by soybean acreage. The fields were systematically sampled from late September through early November, usually after leaf senescence, without regard to foliar or stem symptoms. In each field, 20 stems pieces, approx. 20 $\mathrm{cm}$ long, were collected at just above ground line, and these samples were evaluated for the stem discoloration typical of brown stem rot (34). A random subsample of those field samples was used for fungal isolations in our study. In 1995, 48 subsamples from Iowa and 20 subsamples from each of the other states were used for isolations. In 1996, 50 and 25 subsamples, respectively, were used. In 1995, the subsample selection for isolations was completely random, while the 1996 subsampling was random but restricted to only one subsample per county to increase the geographic distribution of the subsamples from each state. The stem pieces from each field were stored at $4^{\circ} \mathrm{C}$ until isolations, which were completed within 6 months of field collection.

Of the 20 stems randomly collected from each of the subsampled fields, 2 of the most discolored and 2 of the least discolored stems were used for isolation. In a few of the field samples, each of the 20 stems was heavily discolored or each was only lightly discolored, and isolations were attempted from only 2 stems from those fields. Stem pieces were surface sterilized in $0.5 \% \mathrm{NaOCl}$ solution for 2 to $3 \mathrm{~min}$, and four small slivers of the inner stem were excised with a sterile scalpel and placed into $P$. gregata medium (PGM) in a plastic Petri dish (90 $\mathrm{mm}$ in diameter). The PGM (25) is somewhat selective for Phialophora gregata, though other fungi will grow on it at a relatively slow rate. The plates were incubated in the dark for at least 2 weeks at $15^{\circ} \mathrm{C}$ before colonies growing from the stem segments were characterized.

Identifications. Colonies growing from the individual stem pieces were classified into unique mycelial phenotypes based on pigmentation, texture, and relative growth rates. Each of these mycelial phenotypes was given a RFLP-ITS characterization based on HaeIII digests of the ITS region, which was amplified using primers ITS-1F (15) and ITS-4 (31). Template DNA for the PCR was obtained by scraping the colony on the PGM isolation medium lightly with a pipette tip (19). No DNA was extracted.

The PCR reaction mixture $(100 \mu \mathrm{l})$ included 2.5 units of Taq polymerase (Promega Corp., Madison, WI) per reaction, the buffer supplied with the enzyme, $4 \mathrm{mM} \mathrm{MgCl} 2,200 \mu \mathrm{m}$ of dNTPs, and 0.5 $\mu \mathrm{M}$ each primer. The thermocycler (MJ Research, Inc., Watertown, MA) conditions were an initial denaturation at $95^{\circ} \mathrm{C}$ for $95 \mathrm{sec}$, followed by 35 cycles of $52^{\circ} \mathrm{C}$ for $40 \mathrm{sec}$ (annealing), $72^{\circ} \mathrm{C}$ for $2 \mathrm{~min}$ (elongation), and $94^{\circ} \mathrm{C}$ for $30 \mathrm{sec}$ (denaturation). A final elongation was allowed for $10 \mathrm{~min}$ at $72^{\circ} \mathrm{C}$ to ensure a double-stranded amplification product. The amplified DNA was not purified before restriction enzyme digestion. After PCR, the restriction enzyme HaeIII (5 units in $0.5 \mu$ l, Promega Corp.) was added directly to the PCR reaction mix $(17.5 \mu \mathrm{l})$, along with $2.0 \mu$ of $10 \times$ buffer (supplied with the restriction enzyme). The digestion was allowed to proceed for 1 to $16 \mathrm{~h}$ at $37^{\circ} \mathrm{C}$. Both the amplified DNA and the restriction enzyme fragments of these products were electrophoresed separately in $2 \%$ agarose gels in $1 \times$ Tris-borate-EDTA (TBE) buffer
( $89 \mathrm{mM}$ Tris, $89 \mathrm{mM}$ boric acid, $2 \mathrm{mM}$ EDTA, pH 8.0), along with 100 base pair (bp) ladders (Gibco BRL, Inc., Gaithersburg, MD), to determine the size of the amplification and restriction products. The gels were stained with ethidium bromide and visualized using UV light. A digital image of the gel was analyzed using GelReader 2.0.5 (National Center for Supercomputing Applications, University of Illinois, Urbana-Champaign).

For each mycelial/RFLP phenotype found, the ITS region of at least one isolate was sequenced using the ITS-1F and ITS-4 primers. PCR products were purified using Microcon-100 Microconcentrators (Amicon, Inc., Beverly, MA) and sequenced with the ABI PRISM 377 genetic analyzer (PerkinElmer Corp., Norwalk, CT) in the DNA Synthesis and Sequencing Facility at Iowa State University. Sequences of representative isolates were deposited in GenBank (Table 1) and used for searching for similar sequences in various databanks using the BLAST program (version 2.0, National Center for Biotechnology Information, United States National Institutes of Health, Bethesda, MD).

Representative cultures of each mycelial/RFLP phenotype were examined microscopically and compared to descriptions of relatives identified through ITS sequence comparisons. Fusarium spp. were cultured on carnation leaf agar, while potato dextrose agar (PDA) and malt extract agar (MEA) were used for culturing the other species.

Pathogenicity tests. Representative isolates of the nine most common mycelial/RFLP phenotypes in 1995 were used in two duplicate experiments. The susceptible soybean cv. Kenwood was inoculated by placing spores and hyphae into the stem (below the cotyledons, at 1 to $2 \mathrm{~cm}$ above the soil line) of 15-day-old seedlings between the V1 and V2 growth stages (12). In addition to the inoculations of cv. Kenwood, the seven $P$. gregata isolates were also inoculated into cv. BSR101, which is resistant to brown stem rot. Seeds were planted in sterile potting mix (1:2:2 soil:peat:perlite) in pots $(15 \mathrm{~cm}$ in diame-

Table 1. Sizes of the amplified internal transcribed spacer region (ITS) product and HaeIII restriction fragments, and the isolate and accession numbers for the ITS sequence of a representative of each of 11 fungal species identified from soybean stems

\begin{tabular}{|c|c|c|c|c|}
\hline Fungal species & PCR product $(b p)^{y}$ & Size of HaeIII restriction fragments (bp) & Isolate sequenced & Accession number ${ }^{\mathrm{z}}$ \\
\hline Phialophora gregata & 655 & $295,190,160$ & P63 & AF132804 \\
\hline Plectosphaerella cucumerina & 595 & 390,155 & P8 & AF132805 \\
\hline Phomopsis longicolla & 630 & $270,135,100,65$ & P167 & AF132796 \\
\hline Macrophomina phaseolina & 630 & 475,135 & P207 & AF132795 \\
\hline Cladosporium tenuissimum & 600 & 605 & P196 & AF132797 \\
\hline Gliocladium roseum & 615 & 425,130 & P195 & AF132803 \\
\hline Fusarium solani & 615 & $240,130,120,90$ & P185 & AF132801 \\
\hline F. oxysporum 1 & 595 & $350,150,90$ & P179 & AF132799 \\
\hline F. oxysporum 2 & 605 & $265,150,90,75$ & P405 & AF132800 \\
\hline F. graminearum & 595 & $350,150,90$ & $\mathrm{P} 183$ & AF132798 \\
\hline F. acuminatum & 610 & $365,150,90$ & P323 & AF132802 \\
\hline
\end{tabular}

y $\mathrm{PCR}=$ polymerase chain reaction and $\mathrm{bp}=$ base pairs.

${ }^{\text {z }}$ Sequence deposited in GenBank. 
ter, two pots per cultivar/isolate in each of the two experiments) and placed in a growth chamber at $21^{\circ} \mathrm{C}$ and $14 \mathrm{~h}$ of light (330 to $430 \mu \mathrm{Em}^{-2} \mathrm{~s}^{-1}$ ). The plants were thinned to three per pot immediately before inoculations.

Inoculum was obtained from isolates grown on PG- medium (non-acidified PGM without copper sulfate or pentachloronitrobenzene) at $18^{\circ} \mathrm{C}$ for 3 weeks. The agar surface was scraped with a spatula, and a small bit of this slurry was forced into the stem of the soybean seedling with a sterile syringe needle (22 gauge) at 1 to $2 \mathrm{~cm}$ above the soil line. Using a haemocytometer, we determined that a range of $2.25 \times 10^{4}$ to $8.0 \times 10^{4}$ spores of $P$. gregata were picked up by the needle. Control plants were similarly treated but with scrapes of sterile PG-agar medium. After inoculation, the temperature of the growth chamber was set to $17^{\circ} \mathrm{C}$, and the plants were fertilized twice (at 1 and 3 weeks after inoculation) with 1 $\mathrm{g} /$ liter of 20-10-20 fertilizer.

At 5 weeks after inoculation, the plants were harvested and rated for incidence of chlorotic and necrotic leaflets, and the extent of vascular browning above the inoculation point was measured after cutting into the stem. The entire experiment was repeated, and the mean percent of symptomatic leaflets and linear extent of vascular discoloration for each isolate were determined from the 12 inoculated plants. An arcsine transformation of the percent leaflets symptomatic and a $\log _{10}$ transformation of the extent of vascular discoloration were used to normalize the data for analyses comparing the nine fungal species. Analysis of variance (ANOVA) was used to determine if there was variation among the isolates of the nine species in inducing symptoms. The treatment means were separated with the Duncan multiple range test. For comparisons of the $P$. gregata isolates on cvs. Kenwood and BSR101, a two-way ANOVA of non-transformed data was used. All statistical analyses were conducted with the use of SAS software (SAS Institute Inc., Cary, NC).

\section{RESULTS}

Fungal identification. Five putative species of Fusarium and six other fungal species were commonly isolated from discolored and non-discolored soybean stems (Tables 1 and 2). Two of the Fusarium spp. had identical HaeIII restriction patterns of the ITS amplification product (Fig. 1, Table 1) but had differing ITS sequences. Each of the other fungi had unique RFLPs and distinct mycelial morphology. In general, all colonies emanating from the soybean stems that were suspected to be $P$. gregata or Plectosphaerella cucumerina were checked for their ITS-RFLP pattern. Other colonies were tested to establish the consistency of the pattern for each species and to resolve ambiguous groupings based on mycelial morphology. More than 500 colonies were tested for ITS restriction patterns. Representatives of each of the mycelial/RFLP phenotypes were identified to species using microscopic characters and complete DNA sequences of the ITS region.

Three of the isolated species had relatively slow growth rates and only lightly pigmented mycelia on PGM, and microscopic examination showed that they formed Acremonium-like conidiophores (unpigmented and poorly differentiated) and small, unpigmented conidia produced from phialides. Based on these conidiophores and conidia, one of the species was thought to be Phialophora gregata (23). Many of the isolates of the second species formed perithecia and ascospores that matched those described for Plectosphaerella cucumerina (28). The third species formed branching conidiophores with wet droplets of conidia at the branch tips, typical for Gliocladium spp. The RFLPs and ITS sequences of representa- tives of these three taxa (Table 1) differed substantially, thus confirming that they were three separate species.

A search of similar ITS sequences using the BLAST program confirmed the morphological identification of Phialophora gregata and Plectosphaerella cucumerina. The ITS sequences (ITS1, 5.8S rDNA gene, and ITS2) of six of our Phialophora gregata isolates were identical $(100 \%$ match of the $523 \mathrm{bp}$ ) to each other and to that of accessions U66727 and U66729, the ITS sequence of two other $P$. gregata isolates (5). The ITS sequences (ITS1, 5.8S, and ITS2 $=466 \mathrm{bp}$ ) of five soybean isolates of Plectosphaerella cucumerina were identical to each other (though one isolate from a Nicotiana sp. had 9 bp differences from the other five), and the more common ITS sequence was identical to accessions L36640 and U66732 of $P$. cucumerina $(5,27)$. The Gliocladium sp. (isolate P195) had an ITS sequence closest (99\% match, 477 of $481 \mathrm{bp}$ ) to $G$. catenulatum Gilm. (AF048737) and G. penicillioides

Table 2. Percentage of discolored (in vascular system and pith) and non-discolored soybean stems yielding fungal species in isolations on semi-selective medium for Phialophora gregata in 1995 and 1996

\begin{tabular}{lccccc}
\hline & \multicolumn{2}{c}{$\mathbf{1 9 9 5}$} & & \multicolumn{2}{c}{$\mathbf{1 9 9 6}$} \\
\cline { 2 - 3 } \cline { 5 - 6 } Fungal species & $\begin{array}{c}\text { Non-discolored } \\
(\boldsymbol{n}=\mathbf{2 5 6})\end{array}$ & $\begin{array}{c}\text { Discolored } \\
(\boldsymbol{n = 2 5 0})\end{array}$ & & $\begin{array}{c}\text { Non-discolored } \\
(\boldsymbol{n}=\mathbf{2 8 8})\end{array}$ & $\begin{array}{c}\text { Discolored } \\
(\boldsymbol{n}=\mathbf{2 9 0})\end{array}$ \\
\hline Phialophora gregata & 7.8 & 26.8 & & 13.5 & 58.0 \\
Phomopsis longicolla & 69.9 & 52.4 & & 74.3 & 40.0 \\
Macrophomina phaseolina & 7.0 & 10.8 & & 3.1 & 3.4 \\
Cladosporium tenuissimum & 2.0 & 2.8 & & 3.5 & 6.6 \\
Gliocladium roseum & 7.8 & 2.0 & & 1.4 & 2.1 \\
Plectosphaerella cucumerina & 1.6 & 4.4 & & 1.7 & 2.4 \\
Fusarium spp. & 5.8 & 7.2 & & 2.8 & 7.6 \\
Unidentified species & 2.3 & 4.8 & & 5.2 & 4.8 \\
\hline
\end{tabular}

${ }^{\mathrm{z}} n=$ number of stems from which isolations were attempted.

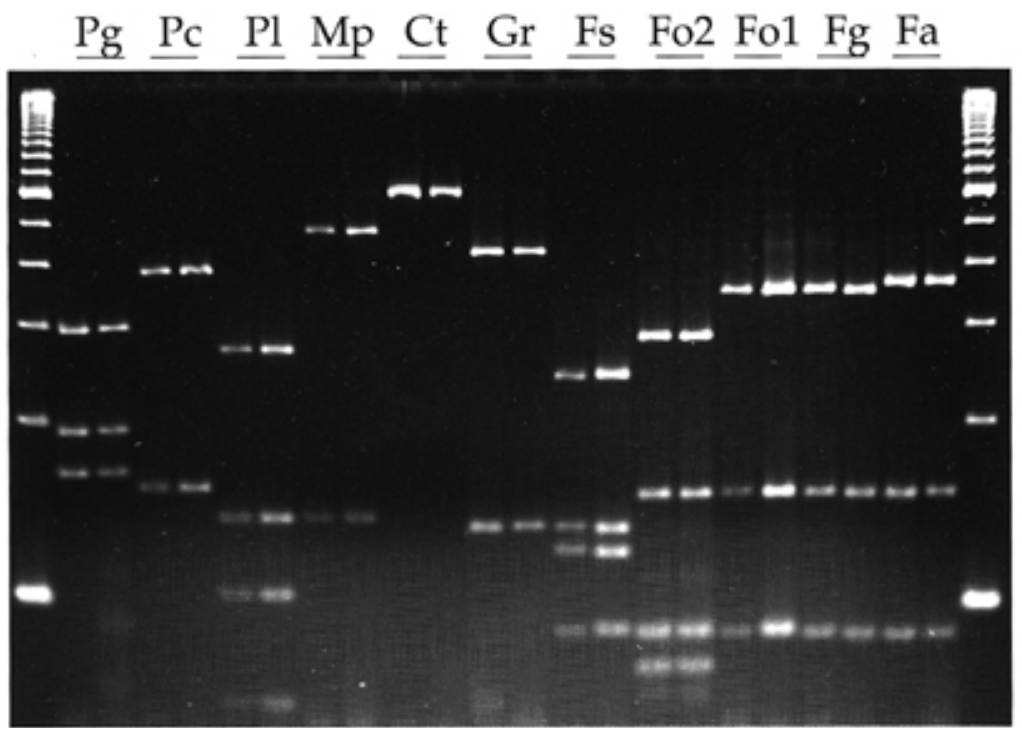

Fig. 1. HaeIII digests of internal transcribed spacer region amplification products of the fungi isolated from discolored soybean stems. Representative products of two isolates of each species are shown. A 100 base pair ladder is shown in the first and last lanes. The fungi are Phialophora gregata $(\mathrm{Pg})$, Plectosphaerella cucumerina $(\mathrm{Pc})$, Phomopsis longicolla $(\mathrm{Pl})$, Macrophomina phaseolina $(\mathrm{Mp})$, Cladosporium tenuissimum. (Ct), Gliocladium roseum (Gr), Fusarium solani (Fs), F. oxysporum (Fo) 2 and $1, F$. graminearum $(\mathrm{Fg})$, and $F$. acuminatum $(\mathrm{Fa})$. 
(AF048733). Our Gliocladium sp. formed Verticillium-like and penicillate conidiophores and fit descriptions of $G$. roseum Banier $(4,9)$, though no ITS sequence of $G$. roseum was available for comparison.

Among the Fusarium spp. isolated, four RFLP patterns were found (Table 1, Fig. 1 ), but two mycelial phenotypes ( $F$. oxysporum sp. 1 and a second species with red colony color on PDA) were found to have the same RFLP pattern. Although the two species had the same RFLP pattern, they had differing ITS sequences. The five unique Fusarium spp. ITS sequences were compared in BLAST searches. The Fusarium sp. with the RFLP pattern of $F$. oxysporum 1 but a red pigment on PDA had a unique ITS sequence (P183) that matched exactly (457 of $457 \mathrm{bp})$ to AF006342 of F. culmorum (W. G. Sm.) Sacc. and U34578 of Gibberella zeae (Schwein.) Petch, and morphologically this species was identified as the anamorph of $G$. zeae, F. graminearum Schwabe. Two species identified as $F$. oxysporum Schlechtend:Fr. (species 1 and 2) based on microscopic characters on carnation agar had differing RFLPs but identical ITS1 sequences, which proved closest to those known for $F$. oxysporum. However, the ITS2 sequences of these two $F$. oxysporum phenotypes differed, as has been noted for other isolates of $F$. oxysporum (26). When the entire ITS sequences were used in BLAST searches, isolate $\mathrm{P} 179$ ( $F$. oxysporum 1) proved closest (455 of $456 \mathrm{bp}$ ) to $F$. oxysporum (U34571, U34566, and $\mathrm{X} 93902)$, and isolate $\mathrm{P} 405$ (F. oxysporum 2) proved closest (469 of $470 \mathrm{bp}$ ) to an unidentified species of Fusarium (U34567). A fourth species, represented by isolate P323, was morphologically identified as $F$. acuminatum Ellis \& Everh. but had an ITS sequence that matched closest (474 of 475 bp) to F. sambucinum Fuckel (U38279). A fifth species was identified as $F$. solani (Mart.) Sacc. based on conidiophore and conidium morphology, and isolate P185 had an ITS sequence nearest to Neocosmospora vasinfecta E. F. Smith
(L36627, 468 of $478 \mathrm{bp}$ ) and Nectria haematococca (Berk. \& Broome) mating population VI (L36620, 464 of $478 \mathrm{bp}$ ) (27).

Three other isolated species were easily distinguished from Phialophora gregata and other soybean isolates by pigmented mycelium or pigmented spores, and each of these three species had unique ITSRFLP patterns (Table 1, Fig. 1). One RFLP pattern was particularly common, and its ITS sequence (isolate P167) matched precisely to accession U97658 (492 of 492 bp matching) of Phomopsis longicolla T. W. Hobbs (35). Several morphological variants were observed among isolates with this RFLP pattern, and these likely represent more than one species in the Diaporthe phaseolorum/Phomopsis longicolla complex (13). Many of the isolates, including isolates P167 and P172, morphologically matched $P$. longicolla according to the criteria of Hobbs et al. (20). Isolate P196 of the Cladosporium sp. had an ITS sequence that matched most closely (459 of $463 \mathrm{bp)}$ to that of C. tenuissimum (Y15966), and it morphologically matched Ellis' (11) description of C. tenuissimum. It also matched morphologically to the description of $C$. cladosporioides (Fres.) de Vries given by Carris and Glawe (4) but not to the $C$. cladosporioides description by Domsch et al. (9), and the ITS sequence of our Cladosporium sp. was closer to that of $C$. tenuissimum than it was to the ITS sequence of C. cladosporioides (L25429; 7). Isolates of the third pigmented species formed microsclerotia typical for Macrophomina phaseolina Petr., and isolate P207 had an ITS sequence closest (484 of 495 bp) to M. phaseolina (U97333).

Isolation frequencies. Phomopsis longicolla was the most commonly isolated fungus from soybean stems in both 1995 and 1996 (Table 2). However, it was isolated more frequently from stems with little or no internal discoloration than from stems with the brown discoloration typical for brown stem rot. In contrast, Phialophora gregata, the second most frequently isolated fungus, was isolated more than three times as frequently from discolored stems than from non-discolored stems. Also, the weather was more conducive (cooler mid-season) and brown stem rot more prevalent in 1996 than in 1995 (F. Workneh and X. B. Yang, unpublished), and $P$. gregata was isolated much more frequently in 1996 than in 1995 (Tables 2 and 3). Macrophomina phaseolina was isolated more frequently in 1995 than in 1996 (Table 2) and was isolated more frequently from samples collected in more southerly sites (Missouri, Ohio, and Illinois) than from more northerly sites (Iowa and Minnesota). Plectosphaerella cucumerina, the five Fusarium spp., Cladosporium tenuissimum, Gliocladium roseum, and isolates that could not be identified were each isolated from fewer than $10 \%$ of the discolored stems (Table 2).

Phialophora gregata was isolated from $50 \%$ of the fields sampled in Iowa in 1995 and from $84 \%$ of the Iowa fields in 1996 , and similar frequencies were found for Minnesota and Illinois fields (Table 3). Fewer of the fields in Ohio and Missouri yielded $P$. gregata. In 1996, when brown stem rot was particularly prevalent, $77 \%$ of the discolored stems from Iowa yielded $P$. gregata, but only 33 and $26 \%$ of the discolored stems from Ohio and Missouri, respectively, yielded $P$. gregata (Table 3).

Pathogenicity tests. When soybean plants were inoculated with representatives of nine species of fungi isolated from soybean stems, only the seven tested $P$. gregata isolates produced the foliar and vascular symptoms of brown stem rot. In both experiments, none of the soybean plants died after 5 weeks, but all of the $P$. gregata-inoculated plants showed vascular discoloration and leaves with chlorosis and necrosis. Isolations on PGM from the inoculated stems yielded the inoculated fungal species 5 weeks after inoculation in all cases, showing that viable inoculum of each of the species was placed into the vascular system.

Table 3. Isolation of Phialophora gregata from non-discolored and discolored soybean stems in 1995 and 1996 from states of the North Central region

\begin{tabular}{|c|c|c|c|c|c|c|}
\hline \multirow[b]{2}{*}{ State, year } & \multicolumn{2}{|c|}{ Fields } & \multicolumn{2}{|c|}{ Non-discolored stems } & \multicolumn{2}{|c|}{ Discolored stems } \\
\hline & Fields sampled (no.) & P. gregata $(\%)$ & Stems sampled (no.) & P. gregata $(\%)$ & Stems sampled (no.) & P. gregata $(\%)$ \\
\hline \multicolumn{7}{|l|}{ Iowa } \\
\hline 1995 & 48 & 50.0 & 96 & 14.6 & 90 & 35.6 \\
\hline 1996 & 50 & 84.0 & 96 & 22.9 & 97 & 77.3 \\
\hline \multicolumn{7}{|l|}{ Illinois } \\
\hline 1995 & 20 & 25.0 & 40 & 0 & 40 & 15.0 \\
\hline 1996 & 25 & 84.0 & 50 & 10 & 49 & 69.4 \\
\hline \multicolumn{7}{|l|}{ Minnesota } \\
\hline 1995 & 20 & 45.0 & 40 & 7.5 & 40 & 32.5 \\
\hline 1996 & 25 & 84.0 & 49 & 18.4 & 49 & 63.3 \\
\hline \multicolumn{7}{|l|}{ Ohio } \\
\hline 1995 & 20 & 35.0 & 40 & 5.0 & 40 & 27.5 \\
\hline 1996 & 25 & 52.0 & 47 & 2.1 & 49 & 32.7 \\
\hline \multicolumn{7}{|l|}{ Missouri } \\
\hline 1995 & 20 & 15.0 & 40 & 2.5 & 40 & 12.5 \\
\hline 1996 & 25 & 32.0 & 46 & 4.3 & 46 & 26.1 \\
\hline
\end{tabular}


The ANOVA for data on percent leaflets chlorotic or necrotic on cv. Kenwood showed significant variation among the isolates $(P=0.0001)$, between the two experiments $(P=0.0007)$, and a significant isolate $\times$ experiment interaction $(P=$ 0.0001). We found significantly less symptom development in the $P$. gregatainoculated plants during the second experiment, apparently due to a brief period of elevated temperature in the growth chamber. A comparison of mean values using Duncan's multiple range test showed that the $P$. gregata isolates caused the greatest leaflet symptoms; the percentage of chlorotic or necrotic leaflets with inoculations with Plectosphaerella cucumerina, M. phaseolina, C. tenuissimum, $F$. oxysporum 1, and $G$. roseum did not differ from that with control inoculations; and inoculations with $F$. oxysporum $2, F$. solani, and Phomopsis longicolla produced an intermediate level of leaflet chlorosis or necrosis (Table 4).

The amount of stem discoloration varied also, with the ANOVA showing a significant variation among isolates $(P=0.0001)$ and an isolate $\times$ experiment interaction $(P$ $=0.0055)$. Only the Phialophora gregatainoculated plants showed the linear extent of discoloration in the stem to be significantly greater than that found in the control inoculations (Table 4). The mean extent of vascular discoloration in the susceptible cv. Kenwood after inoculation with the seven P. gregata isolates ranged from 67 to 117 mm (Table 4).

In comparably inoculated plants of cv. BSR101, which carries resistance to brown stem rot, all plants showed symptoms of brown stem rot after inoculation with the $P$. gregata isolates. The mean extent of vascular discoloration in BSR101 of the seven P. gregata isolates ranged from 74 to 89 $\mathrm{mm}$, and the mean percent of leaflets showing symptoms ranged from 30 to $52 \%$ (Table 4). The two-way ANOVA (Table 5) showed significant variation among iso- lates, cultivars, and the two experiments, and significant cultivar $\times$ isolate interactions for percent leaflets symptomatic. Also, ANOVA found significant variation in the linear extent of stem discoloration among isolates and between the two experiments, and there was significant experiment $\times$ isolate interaction (Table 5). Although the cultivars did not differ overall in the extent of linear discoloration of the stem, there was significant isolate $x$ cultivar interaction. Isolations from the inoculated stems of both cvs. Kenwood and BSR101 yielded P. gregata.

\section{DISCUSSION}

The use of rDNA sequences allowed unequivocal delimitation of fungal species associated with discolored stems of soybeans. P. gregata was isolated commonly from soybean stems showing brown discoloration of the vascular system. Of nine tested species of fungi from soybean stems, only the seven tested $P$. gregata isolates produced the vascular discoloration and leaf symptoms typical of brown stem rot. Symptoms were produced in both the susceptible (Kenwood) and the resistant (BSR101) soybean cultivars, with slightly less discoloration of stems and leaves in the more resistant cultivar. $P$. gregata was reisolated from the inoculated soybean plants, thus completing Koch's postulates.

Phomopsis longicolla (the Diaporthe phaseolorum complex) was also frequently isolated from soybean stems, but it was more frequently isolated from lightly or non-discolored stems than from discolored stems. Members of this species complex are very common on soybeans, colonizing the plants late in the season as they senesce (30), and our isolations were made from stems late in the season, generally after leaf senescence and sometimes after harvest. Aside from P. longicolla and Phialophora gregata, the other fungal species were isolated much less frequently, and there was generally little difference in the frequency of isolation between discolored and non-discolored stems. Under our test conditions, none of these species could induce the vascular browning and leaf symptoms typical of brown stem rot (17). Phomopsis longicolla causes seed decay and may cause a stem blight (30), and $M$. phaseolina causes charcoal rot of stressed plants (32), but few symptoms were produced in our inoculations, perhaps because the inoculated seedlings were harvested only 5 weeks after inoculations. It should also be noted that these two species did not produce conidia on the agar medium used to harvest inoculum for our study, but the species did become established in the inoculated plants because they were successfully reisolated after 5 weeks.

Fusarium spp. have been associated with disease of soybean (8), but none of the Fusarium spp. encountered proved to be effective vascular wilt fungi in our inoculations. A form of $F$. solani with a unique ITS sequence (27) causes sudden death syndrome of soybean, but the sudden death syndrome pathogen does not grow on PGM and our isolates of $F$. solani had a different RFLP pattern and ITS sequence than the sudden death syndrome pathogen. Plectosphaerella cucumerina has been confused with the $F$. solani associated with sudden death syndrome of soybean $(1,27)$ and has been isolated from cysts of the soybean cyst nematode (4). It has been isolated from many plant species (28) and may be a weak pathogen on some (6), though it does not appear to be a pathogen on soybean.

In Iowa, Illinois, and Minnesota, $84 \%$ of the randomly sampled soybean fields and more than $63 \%$ of the discolored stems yielded Phialophora gregata in 1996, a year with a high incidence of brown stem rot (F. Workneh and X. B. Yang, unpublished). Incidences of $P$. gregata were lower in Ohio and Missouri, especially in 1995, a relatively warm growing season. Only 3 of the 20 sampled fields from Mis-

Table 4. Percent leaflets symptomatic and linear extent of vascular discoloration in inoculated stems of the soybean cvs. Kenwood and BSR101

\begin{tabular}{|c|c|c|c|c|c|}
\hline \multirow[b]{2}{*}{ Species } & \multirow[b]{2}{*}{ Isolate no. } & \multicolumn{2}{|c|}{ Kenwood } & \multicolumn{2}{|c|}{ BSR101 } \\
\hline & & Leaflets $(\%)$ & Discoloration (mm) & Leaflets (\%) & Discoloration (mm) \\
\hline Phialophora gregata & P19 & $59 \mathrm{a}$ & $98 \mathrm{a}$ & $37 \mathrm{~b}$ & $88 \mathrm{a}$ \\
\hline$P$. gregata & P113 & $52 \mathrm{ab}$ & $97 \mathrm{a}$ & $36 \mathrm{~b}$ & $81 \mathrm{a}$ \\
\hline P. gregata & P129 & $51 \mathrm{ab}$ & $92 \mathrm{a}$ & $39 \mathrm{~b}$ & $74 \mathrm{a}$ \\
\hline P. gregata & P126 & $46 \mathrm{~b}$ & $117 \mathrm{a}$ & $38 \mathrm{~b}$ & $89 \mathrm{a}$ \\
\hline P. gregata & P21 & $46 \mathrm{~b}$ & 96 a & $52 \mathrm{a}$ & $81 \mathrm{a}$ \\
\hline P. gregata & P115 & $27 \mathrm{c}$ & $90 \mathrm{a}$ & $30 \mathrm{~b}$ & $87 \mathrm{a}$ \\
\hline P. gregata & P109 & $26 \mathrm{c}$ & $67 \mathrm{~b}$ & $32 \mathrm{~b}$ & $83 \mathrm{a}$ \\
\hline Fusarium oxysporum type 2 & P175 & $12 \mathrm{~d}$ & $10 \mathrm{~cd}$ & ND & ND \\
\hline Fusarium oxysporum type 1 & P188 & 5 def & $8 \mathrm{~cd}$ & ND & ND \\
\hline Fusarium solani & P185 & $9 \mathrm{de}$ & $3 \mathrm{~cd}$ & ND & ND \\
\hline Phomopsis longicolla & P172 & $10 \mathrm{de}$ & $0 \mathrm{~d}$ & ND & ND \\
\hline Cladosporium tenuissimum & P199 & $5 \mathrm{def}$ & $0 \mathrm{~d}$ & ND & ND \\
\hline Gliocladium roseum & P191 & $2 \mathrm{ef}$ & $7 \mathrm{~cd}$ & ND & ND \\
\hline Macrophomina phaseolina & P203 & $1 \mathrm{f}$ & $0 \mathrm{~d}$ & ND & ND \\
\hline Plectosphaerella cucumerina & P156 & $0 \mathrm{f}$ & $0 \mathrm{~d}$ & ND & ND \\
\hline P. cucumerina & P161 & $0 \mathrm{f}$ & $0 \mathrm{~d}$ & ND & ND \\
\hline Control & $\ldots$ & $0 \mathrm{f}$ & $0 \mathrm{~d}$ & ND & ND \\
\hline
\end{tabular}

${ }^{\mathrm{z}}$ Means within a column followed by the same letter not significantly different $(P=0.05)$ based on Duncan's Multiple Range Test. ND $=$ not determined. 
souri yielded $P$. gregata in 1995 . The lower incidence of the fungus from the more southerly locations, and the lower incidence in 1995 compared to 1996, may be due to the low temperature requirements of $P$. gregata (23). Nonetheless, the recovery of $P$. gregata was generally high, and brown stem rot appears to be one of the more common of the major diseases of soybean in the upper Midwest (10).

In this study, we relied heavily on the restriction fragments of the ITS region and on ITS sequences to classify and tentatively identify isolates, and the HaeIII-ITS patterns proved to be an objective criterion for identifying $P$. gregata and similar species from discolored soybean stems. Because the ITS region could be amplified directly from scrapes of mycelium on the isolation medium, and because the HaeIII restrictions could be done in the PCR reaction buffer, it was relatively easy to determine the RFLP pattern of 50 isolates in a single day. The ITS product was readily obtained with most of the species, although Phomopsis longicolla proved more difficult than the rest. The taxonomically difficult genus Fusarium was relatively easy to characterize by ITS-RFLPs, but the ITS sequences were only partially successful in identifying these species. Other fungi could be identified to species, or at least closely related species were suggested, through ITS sequences. Phialophora gregata and Plectosphaerella cucumerina, the most difficult species to distinguish based on morphology, were readily amenable to ITS amplification from mycelial scrapes. These two species commonly grow together in mixed culture and, when ITS amplification was attempted from scrapes of such mixed mycelia, the ITS product of $P$. cucumerina was most frequently produced.

With our isolation and identification techniques, and the subsequent patho- genicity tests, we were able to clarify that only Phialophora gregata is capable of causing brown stem rot. The earlier association of other Acremonium-like fungi with brown stem rot $(5,18,23)$ may be due to the presence of Plectosphaerella cucumerina, Gliocladium roseum, or other Acremonium-type fungi not encountered in our study. Neither $P$. cucumerina nor $G$. roseum were capable of causing brown stem rot in our inoculations, though an unidentified Acremonium sp. did cause vascular discoloration in an earlier study (23). The conflicting reports $(16,23,25,33)$ of defoliating and non-defoliating forms of Phialophora gregata on soybean are difficult to reconcile without examination of the so-called type II (non-defoliating) isolates, the strains that induced vascular discoloration but not foliar symptoms in inoculation tests $(16,23,33)$. It is possible that some reports of the non-defoliating form are actually Plectosphaerella cucumerina, and type II colonies illustrated by Mengistu et al. (25) look like those of $P$. cucumerina. We have inadvertently inoculated soybeans with mixed cultures of $P$. cucumerina and Phialophora gregata and found erratic production of foliar symptoms with limited vascular discoloration. Alternatively, the non-defoliating isolates may represent a less aggressive form of $P$. gregata.

The $P$. gregata HaeIII-ITS pattern was diagnostic for the species because it was not found in any of the other fungal species isolated from discolored stems of soybean. We sequenced the ITS region of eight isolates of $P$. gregata and found the sequences to be identical, and the unique HaeIII digestion pattern was found with the more than 300 isolates tested to date. However, we did see variation in aggressiveness among the seven tested isolates of $P$. gregata on both cvs. Kenwood and BSR101, and significant isolate $\times$ cultivar interac-

Table 5. Two-way analysis of variance of percent leaflets symptomatic and linear extent of xylem discoloration in soybean plants (cvs. Kenwood and BSR101) inoculated with seven isolates of Phialophora gregata

\begin{tabular}{|c|c|c|c|c|}
\hline Symptom, source of variation & $\mathbf{d f}^{\mathbf{z}}$ & Mean square & $F$ value & $P>F$ \\
\hline \multicolumn{5}{|l|}{ Leaflets symptomatic } \\
\hline Isolates & 6 & $1,767.1$ & 10.0 & 0.0001 \\
\hline Cultivars & 1 & $1,552.1$ & 8.78 & 0.0036 \\
\hline Cultivar $\times$ isolate & 6 & 779.4 & 4.41 & 0.0004 \\
\hline Experiments & 1 & $13,945.6$ & 78.89 & 0.0001 \\
\hline Isolate $\times$ experiment & 6 & 92.0 & 0.52 & 0.7922 \\
\hline Cultivar $\times$ experiment & 1 & 539.1 & 3.05 & 0.0831 \\
\hline Cultivar $\times$ isolate $\times$ experiment & 6 & 138.4 & 0.78 & 0.5847 \\
\hline Replicates (experiment) & 10 & 199.8 & 1.13 & 0.3447 \\
\hline \multicolumn{5}{|l|}{ Vascular discoloration } \\
\hline Isolates & 6 & $33,009.1$ & 2.59 & 0.0208 \\
\hline Cultivars & 1 & $9,143.8$ & 0.72 & 0.3981 \\
\hline Cultivar $\times$ isolate & 6 & $32,667.7$ & 2.57 & 0.0220 \\
\hline Experiments & 1 & $263,557.3$ & 20.72 & 0.0001 \\
\hline Isolate $\times$ experiment & 6 & $42,421.4$ & 3.33 & 0.0044 \\
\hline Cultivar $\times$ experiment & 1 & 28.6 & 0.0 & 0.9622 \\
\hline Cultivar $\times$ isolate $\times$ experiment & 6 & $22,797.8$ & 1.79 & 0.1056 \\
\hline Replicates (experiment) & 10 & $7,715.3$ & 0.61 & 0.8061 \\
\hline
\end{tabular}

${ }^{\mathrm{z}}$ Degree of freedom.

tion in leaflet symptoms was seen, with isolates P109 and P115 causing significantly less leaflet discoloration on Kenwood than did the other isolates of $P$. gregata. However, each of the seedlings inoculated with these isolates of $P$. gregata caused some foliar symptoms, and none could be considered type II isolates sensu Gray (16), Mengistu and Grau (23), or Willmot et al. (33). Because of such ambiguity, we propose that the terms "non-defoliating" and "type II" not be applied to $P$. gregata. Variation in aggressiveness among $P$. gregata strains is under investigation, and preliminary work shows that variation in the degree of symptoms caused by Midwestern strains of $P$. gregata is high, as has been found with the adzuki bean pathogen, P. gregata f. sp. adzukicola (22), but all soybean isolates of $P$. gregata appear capable of causing foliar symptoms, even in the resistant cv. BSR101.

\section{ACKNOWLEDGMENTS}

We thank G. Munkvold for his help in identifying the Fusarium spp. and reviewing the manuscript, J. Mihail for identifying Macrophomina phaseolina isolates, M. Palm for providing isolates of Plectosphaerella cucumerina, and C. Grau for supplying isolates of Phialophora gregata and Plectosphaerella cucumerina from Wisconsin for comparisons.

\section{LITERATURE CITED}

1. Abney, T. S., Richards, T. L., and Roy, K. W. 1993. Fusarium solani from ascospores of Nectria haematococca causes sudden death syndrome of soybean. Mycologia 85:801-806.

2. Allington, W. B., and Chamberlain, D. W. 1948. Brown stem rot of soybean. Phytopathology 38:793-802.

3. Bachman, M. S., Nickell, C. D., Stephens, P. A., and Nickell, A. D. 1997. Brown stem rot resistance in soybean germplasm from central China. Plant Dis. 81:953-956.

4. Carris, L. M., and Glawe, D. A. 1989. Fungi colonizing cysts of Heterodera glycines. Univ. Ill. Coll. Agric. U. S. Dep. Agric. Bull. 786.

5. Chen, W., Gray, L. E., and Grau, C. R. 1996. Molecular differentiation of fungi associated with brown stem rot and detection of Phialophora gregata in resistant and susceptible soybean cultivars. Phytopathology 86:11401148.

6. Chung, Y. R., Koo, S. J., Kim, H. T., and Cho, K. Y. 1998. Potential of an indigenous fungus, Plectosporium tabacinum, as a mycoherbicide for control of arrowhead (Sagittaria trifolia). Plant Dis. 82:657-660.

7. Curtis, M., Gore, J., and Oliver, R. 1994. The phylogeny of the tomato leaf mould fungus Cladosporium fulvum syn. Fulvia fulva by analysis of rDNA sequences. Curr. Genet. 25:318-322.

8. Datnof, L. E. 1989. Fusarium blight or wilt, root rot, and pod and collar rot. Pages 33-35 in: Compendium of Soybean Diseases, 3rd ed. J. B. Sinclair and P. A. Backman, eds. American Phytopathological Society, St. Paul, MN.

9. Domsch, K. H., Gams, W., and Anderson, T.H. 1980. Compendium of Soil Fungi, Volume 1. Academic Press, London.

10. Doupnik, B., Jr. 1993. Soybean production and disease loss estimates for the north central United States from 1989-1991. Plant Dis. 77:1170-1171.

11. Ellis, M. B. 1976. More Dematiaceous Hyphomycetes. Commonw. Mycol. Inst. Kew, 
England.

12. Fehr, W. R., Caviness, C. E., Burmood, D. T., and Pennington, J. S.. 1971. Stage of development descriptions for soybeans, Glycine $\max ($ L.) Merr. Crop Sci. 11:929-931.

13. Fernández, F. A., and Hanlin, R. T. 1996. Morphological and RAPD analyses for Diaporthe phaseolorum from soybean. Mycologia 88:424-440.

14. Gams, W. 1971. Cephalosporium-artige Schimmelpilze (Hyphomycetes). Gustav Fischer Verlag, Stuttgart, Germany.

15. Gardes, M., and Bruns, T. D. 1993. ITS primers with enhanced specificity for basidiomycetes-application to the identification of mycorrhizae and rusts. Mol. Ecol. 2:113-118.

16. Gray, L. E. 1971. Variation in pathogenicity of Cephalosporium gregatum isolates. Phytopathology 61:1410-1411.

17. Gray, L. E. 1989. Brown stem rot. Pages 2930 in: Compendium of Soybean Diseases, 3rd ed. J. B. Sinclair and P. A. Backman, eds. American Phytopathological Society, St. Paul, $\mathrm{MN}$.

18. Gray, L. E., and Hepburn, A. G. 1992. Mitochondrial DNA restriction patterns of Phialophora gregata isolates from soybean and adzuki bean. Phytopathology 82:211-215.

19. Harrington, T. C., and Wingfield, B. D. 1995. A PCR-based identification method for species of Armillaria. Mycologia 87:280-288.

20. Hobbs, T. W., Schmitthenner, A. F., and Kuter, G. A. 1985. A new Phomopsis species from soybean. Mycologia 77:535-544.

21. Kobayashi, K. Yamamoto, H., Negishi, H., and Ogoshi, A. 1991. Forma specialis differentiation of Phialophora gregata isolates from adzuki bean in Japan and from soybean in the United States. Ann. Phytopathol. Soc. Jpn. 57:225-231.

22. Kondo, N., Fujita, S., Murata, K., and Ogoshi, A. 1998. Detection of two races of Phialophora gregata f. sp. adzukicola, the causal agent of adzuki bean brown stem rot. Plant Dis. 82:928-930.

23. Mengistu, A., and Grau, C. R. 1986. Variation in morphological, cultural, and pathological characteristics of Phialophora gregata and Acremonium sp. recovered from soybean in Wisconsin. Plant Dis. 70:1005-1009.

24. Mengistu, A., Grau, C. R., and Gritton, E. T. 1986. Comparison of soybean genotypes for resistance to and agronomic performance in the presence of brown stem rot. Plant Dis. 70:1095-1098.

25. Mengistu, A., Tachibana, H., and Grau, C. R. 1991. Selective medium for isolation and enumeration of Phialophora gregata from soybean straw and soil. Plant Dis. 75:196199.

26. O'Donnell, K., and Cigelnik, E. 1997. Two divergent intragenomic rDNA ITS2 types within a monophyletic lineage of the fungus Fusarium are nonorthologous. Mol. Phylogenet. Evol. 7:103-116.

27. O'Donnell, K., and Gray, L. E. 1997. Phylogenetic relationships of the soybean sudden death syndrome pathogen Fusarium solani f. sp. phaseoli inferred from rDNA sequence data and PCR primers for its identification. Mol. Plant-Microbe Interact. 8:709-716.

28. Palm, M. E., Gams, W., and Nirenberg, H. I. 1995. Plectosporium, a new genus for Fusarium tabacinum, the anamorph of Plectosphaerella cucumerina. Mycologia 87:397-406.

29. Phillips, D. V. 1973. Variation in Phialophora gregata. Plant Dis. Rep. 57:1063-1065

30. Schmitthenner, A. F. 1989. Pod and stem blight and Phomopsis seed decay. Pages 39. 41 in: Compendium of Soybean Diseases, 3rd ed. J. B. Sinclair and P. A. Backman, eds American Phytopathological Society, St. Paul, MN.

31. White T. J., Bruns, T. D., Lee, S., and Taylor J. 1990. Amplification and direct sequencing of fungal ribosomal RNA genes for phylogenetics. Pages 315-322 in: PCR Protocols: a Guide to Methods and Application. M. A. Innis, D. H, Gelfand, J. J. Sninsky, and T. J. White, eds. Academic Press, San Diego, CA.

32. Willie, T. D. 1989. Charcoal rot. Pages 31-33 in: Compendium of Soybean Diseases, 3rd ed. J. B. Sinclair and P. A. Backman, eds. American Phytopathological Society, St. Paul, MN.

33. Willmot, D. B., Nickell, C. D., and Gray, L. E. 1989. Physiologic specialization of Phialophora gregata on soybean. Plant Dis. 73:290294.

34. Workneh, F., Tylka, G. L., Yang, X. B. Faghihi, J., and Ferris, J. M. 1999. Regional assessment of soybean brown stem rot, Phy tophthora sojae, and Heterodera glycines using area-frame sampling: prevalence and ef fects of tillage. Phytopathology 89:204-211.

35. Zhang, A. W., Hartman, G. L., Riccioni, L., Chen, W. D., Ma, R. Z., and Pedersen, W. L. 1997. Using PCR to distinguish Diaporthe phaseolorum and Phomopsis longicolla from other soybean fungal pathogens and to detect them in soybean tissues. Plant Dis. 81:11431149 